\title{
応力分布下の平滑表面に打ける応力腐食割れの

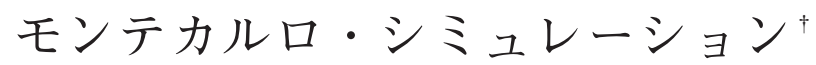

$\begin{array}{llllll}\text { 鈴 } & \text { 洋 } \text { 光* }^{*} \text { 東 郷 敬一郎** 島 村 佳 伸** } \\ \text { 中 山 } & \text { 元 }^{* *} \text { 平 野 } & \text { 隆*** } & & & \end{array}$

\section{Monte Carlo Simulation of Stress Corrosion Cracking on Smooth Surface under Non-Uniform Stress Condition}

\author{
by
Hiromitsu Suzuki ${ }^{*}$, Keiichiro Tohgo ${ }^{* *}$, Yoshinobu Shimamura ${ }^{* *}$, Guen NAKAYAMA $^{* * *}$ and Takashi HIRANO ${ }^{* * *}$

\begin{abstract}
A Monte Carlo simulation model for the process of stress corrosion cracking (SCC) in structural metal materials under non-uniform stress condition has been proposed. The possible number of crack initiations is set for a given space and initiation times for all cracks are assigned by random numbers based on exponential distributions depending on stress level. Sites and lengths of the cracks are assigned by random numbers based on uniform distribution and normal distribution, respectively. Coalescence of cracks and subcritical crack growth are determined based on the fracture mechanics concept. Through the SCC process in the model, the influence of semi-elliptical surface cracks is taken into consideration. SCC simulations were carried out on a smooth surface under two kinds of non-uniform stress conditions such as residual stress distribution around a weld line. Multiple parallel cracks and multiple cracks along narrow high stress region were obtained depending on the stress distributions, respectively. Simulation results exhibit the applicability of the model to describe the SCC behavior observed in real structures.
\end{abstract}

Key words : Stress corrosion cracking, Monte Carlo simulation, Crack initiation, Crack coalescence, Subcritical crack growth, Surface crack, Non-uniform stress condition

\section{1 緒言}

近年，国内外に扎て原子炉等の発電プラント内構造 物に経年劣化事象である応力腐食割れ (SCC) による損 傷事例が顕在化している．高経年化した構造物のより高 度な安全管理を行っていくには，SCC 対策は重要な課題 である.SCC は材料, 環境および応力の組み合わせによ り生ずる極めて複雑な破壊現象であり，き裂長さは数 $10 \mathrm{~mm}$ から数 $100 \mathrm{~mm}$ に及ぶ場合がある。このような大 き裂は，腐食ピットの発生・成長，ピットからの微小き 裂の発生, 微小き裂の合体・進展, 巨視的き裂の進展と 合体といったミクロからマクロにわたる過程により形成 され，SCC 挙動は階層構造を示すことがわかる.1) 7)こ の SCC 挙動の各階層における現象を明らかにし, 各階層 の統合化を行い, SCC 挙動の全過程を考慮できるならば, 実構造物中の SCC 挙動をより精度よく予測できるもの と推察される。

その手法の一つとして, モンテカルロ法によるシミュ レーションが挙げられ，これまでに，平滑表面の SCC 挙 動と同様に, 腐食疲労, クリープ疲労, 高温環境下での 破壊現象に対して微小分布き裂の発生・合体・進展のシ ミュレーションが行われている.8) 12)著者らは, 一様応
力場での SCC に打ける微小き裂の発生から合体・進展 により大き裂が形成される過程のモンテカルロ・シミュ レーションを開発し, 表面き裂効果を考慮することの重 要性を指摘した。さらに, シミュレーション結果に及ぼ すき裂発生速度および合体領域の影響を考察した. ${ }^{13), 14)}$

実構造物中では，溶接熱サイクルによる SCC 鋭敏化と 溶接残留応力により溶接部近傍に多数の SCC 表面き裂 が報告されている。例えば，Fig. 1 に示す溶接線表面近 傍の溶接残留応力による SCC を考えると，Fig. 1 (a)では

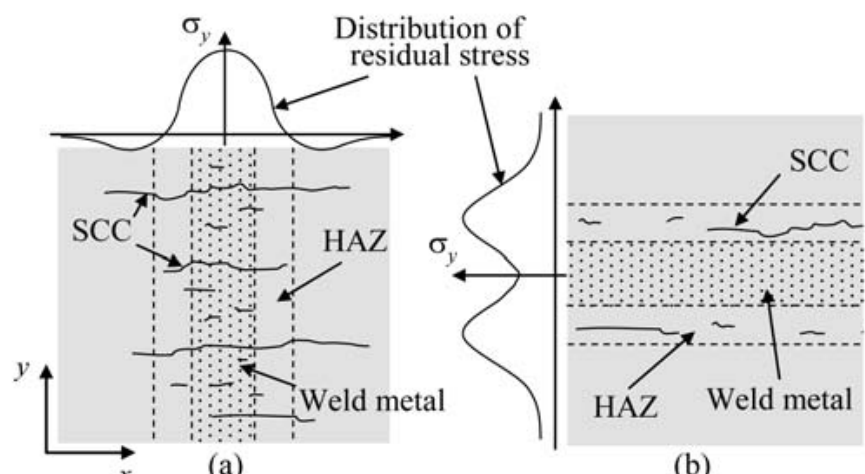

(a)

Fig. 1 SCC on residual stress field.

$\dagger$ 原稿受理 平成 20 年 4 月 17 日 Received Apr. 17, 2008 @ 2008 The Society of Materials Science, Japan

* 静岡大学大学院 干432-8561 浜松市中区城北, Shizuoka Univ., Naka-ku, Hamamatsu, 432-8561

$* *$ 正会員 静岡大学工学部 †432-8561 浜松市中区城北, Shizuoka Univ., Naka-ku, Hamamatsu, 432-8561

$* * * \quad$ (株) IHI＝235-8501＼cjkstart横浜市磯子区新中原町, IHI Corporation, Isogo-ku, Yokohama, 235-8501 


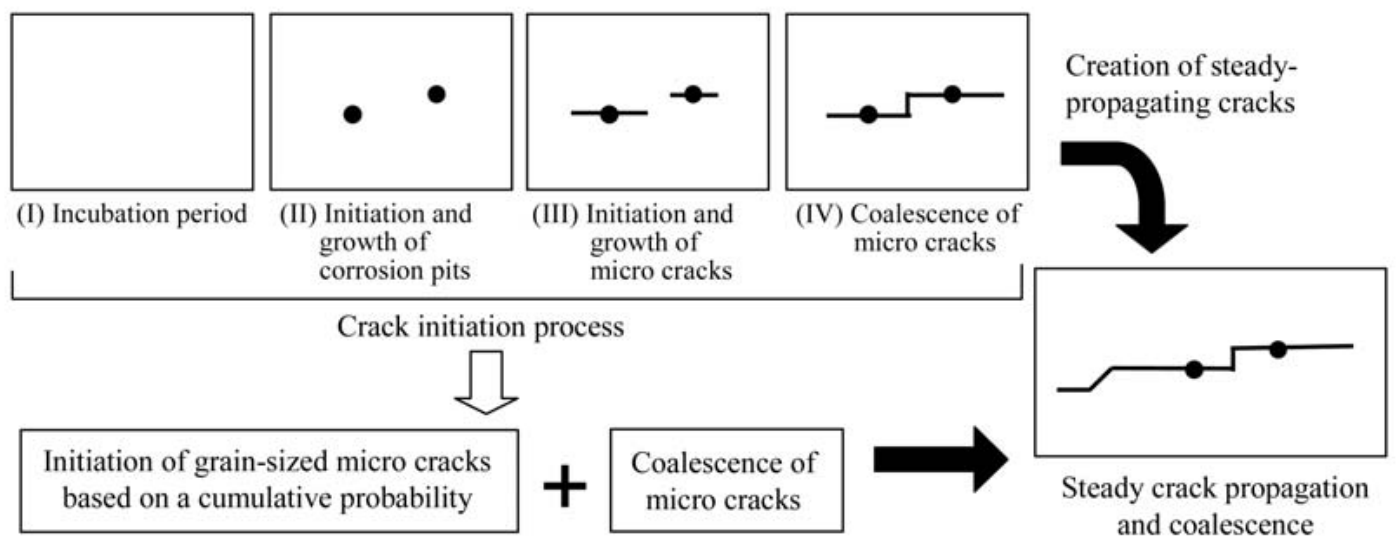

Fig. 2 A model of SCC behavior.

溶接線方向の応力により溶接線に垂直な多数のき裂が, Fig. 1 (b)では溶接線垂直方向の応力により熱影響部 (HAZ) に沿ったき裂が予想され，類似の事例が報告され

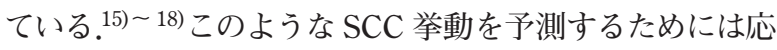
力分布を考虑することが重要となる。そこで，本研究で は, 前報 ${ }^{14)}$ で開発した一様応力場での SCC 挙動のモン テカルロ・シミュレーションを応力分布が考虑できるよ うに拡張した。

\section{2 構造材料における SCC 挙動}

SCC 環境下では, Fig. 2 に示すように, (I) 潜伏過程, (II) 腐食ピットの形成過程, (III) 腐食ピットからの結晶 粒オーダー微小き裂の形成過程, (IV) 微小き裂の合体過 程を経て, 進展性き裂が形成され，その後のき裂進展と 合体により大き裂へと成長する.1) 3)すなわち，SCCによ る大き裂は進展性き裂が形成されるまでのミクロな過程 からその後のマクロな過程を経て形成される。腐食ピッ 卜，微小き裂に関する詳細な実験, 観察により (II) と (III) はポアソン確率過程となり, 微小き裂の発生数はポアソ ン分布に従うことが報告されている。したがって，進展性 き裂の発生過程は潜伏期間を有する指数分布に従う結晶 粒オーダーの微小き裂の発生過程と微小き裂の合体過程 により表現できることがわかる．時間 $t$ に打けるき裂発生 の累積確率 $F_{\mathrm{i}}(t)$ は次式のように指数分布により表される.

$$
F_{t}(t)=1-\exp \left\{-\frac{\left(t-a_{i}\right)}{\theta_{i}}\right\}=1-\exp \left\{-H_{i}(t)\right\}
$$

ここで, $H_{i}(t)$ は累積故障率, $a_{i}$ は分布の下限界値あるい は潜伏期間を表す位置パラメータで， $\theta_{i}$ は標準偏差を表 す尺度パラメータである。 $a_{i}$ と $\theta_{i}$ は一般には作用応力と 環境の関数として与えられる。このようにして発生した き裂は隣接して発生したき裂と合体することにより，定 常進展の臨界長さに達し, 炎の後, 合体と進展により大 きなき裂へと成長する。

もし , Fig. 3 (a)に示すように, 応力分布が存在するよ うな場合は, 式 (1) は応力に依存して $a_{i}$ と $\theta_{i}$ は変化し, 応力の高い所では，き裂は発生しやすく，また，き裂先 端応力場も高くなるので, き裂進展, 合体も生じやすく なるということになる.

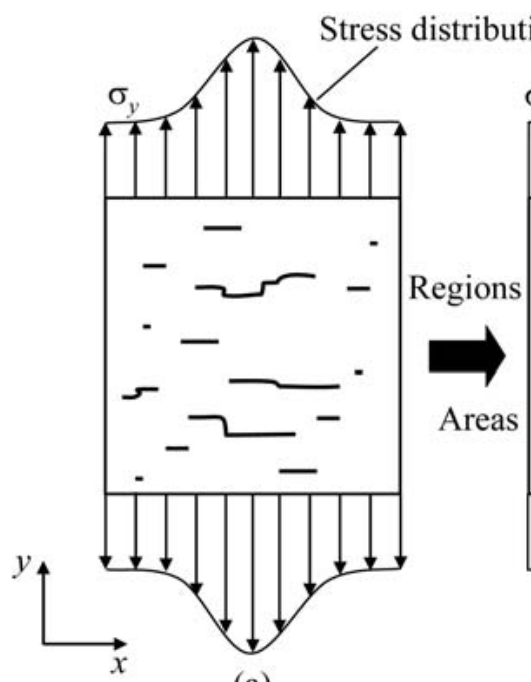

(a)

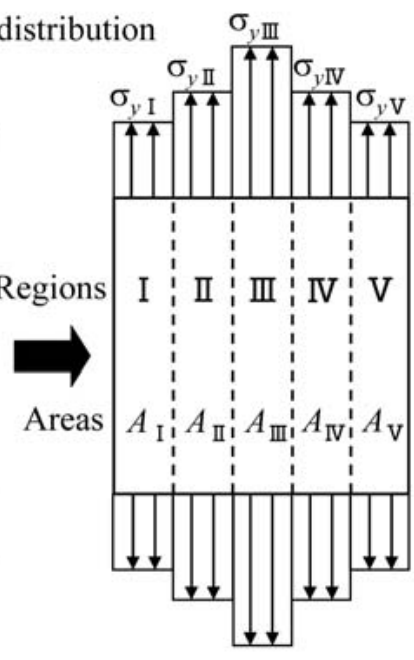

(b)
Fig. 3 Simulation area under non-uniform stress condition.

\section{$3 \mathrm{SCC}$ 過程のモデル化}

Fig. 4 にシミュレーションのフローチャートを示す. 本研究では Fig. 3 (a)に示すような応力分布下に打ける SCC 挙動を解析するために, Fig. 3 (b)のように解析領 域を $\mathrm{n}$ 個に分割し, 個々の領域では領域平均の一様な応 力場となる問題を考える。 な拉，平滑表面から内部方向 への応力分布は考虑せず，表面での応力分布が内部でも 続くものと考える.

Step 1 : 発生するき裂は, 表面長さ $2 a$, 深さ $b$, アス ペクト比 $b / a=\alpha$ の半楕円表面き裂とする. 結晶粒オ一 ダーの粒界き裂が引張応力方向にほぼ垂直に発生すると 考えられる. 従って, 1 結晶粒領域に 1 個のき裂発生が 可能なので, 平滑表面での平均結晶粒面積 (Average grain area）を用いて, $i$ 番目領域（面積 $A_{i}$ ) に発生可能 なき裂数は式 (2)により与えられ, 全領域では式 (3)で与 えられる。

$$
\begin{aligned}
& N_{\max i}=\frac{A_{i}}{\text { Averagegrain area }} \\
& N_{\text {max }}=N_{\max 1}+\cdots+N_{\text {maxn }}
\end{aligned}
$$

Step $2: N_{\text {max }}$ 個のき裂に対するき裂発生時間は, $\mathrm{n}$ 個 に分割された領域ごとに与えられるき裂発生の累積確率 


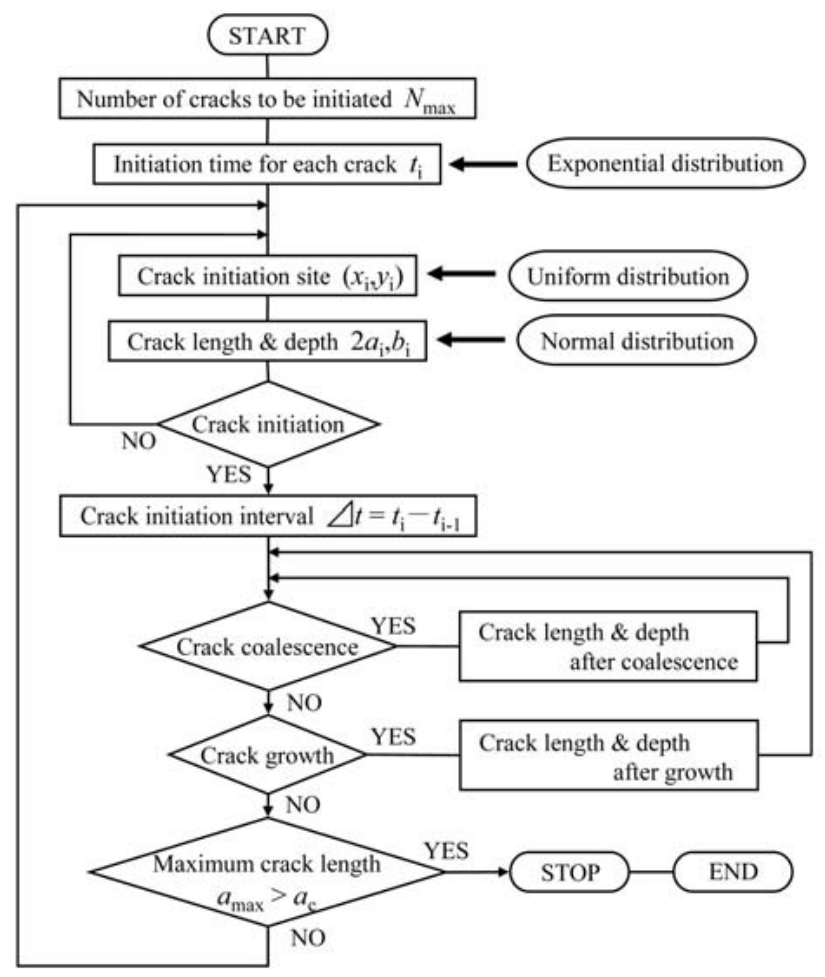

Fig. 4 Flow chart of SCC simulation.

分布 $F_{\mathrm{i}}(t)$ に基づく乱数により決定される.

Step 3 : き裂は割り当てられた発生時間の短いものか ら順に発生させ，き裂発生位置は発生時間を与えた領域 に打ける一様乱数により，き裂長さは正規乱数により決 定される. Fig. 5 に示すように，既存のき裂の上下は応 力解放によりき裂の発生がしにくい場所となるので, 裂発生位置がそのような場所になったときは，き裂は発 生できないものとし，次のき裂発生が発生時間，位置， 長さに対する新しい乱数に基づいて試みられる.

Step 4 ：き裂発生が可能となった場合，直前のき裂発 生からの時間 $\Delta t$ におけるき裂の進展，合体が各表面き裂 の表面部, 最深部の応力拡大係数 $K_{\mathrm{IA}}, K_{\mathrm{IB}}$ に基づいて計 算される. $K_{\mathrm{IA}}, K_{\mathrm{IB}}$ は Fig. 6 の修正係数を用いて次式に より評価した.19)

$$
\begin{aligned}
& K_{\mathrm{IA}}=F_{\mathrm{IA}} \sigma_{y} \sqrt{\pi a} \\
& K_{\mathrm{IB}}=F_{\mathrm{IB}} \sigma_{y} \sqrt{\pi b}
\end{aligned}
$$

また，き裂が小さく一つの分割領域内に存在する場合に はその領域の応力值を用いて計算し，き裂が領域をまた いで存在する場合は，き裂表面部，最深部が存在する領

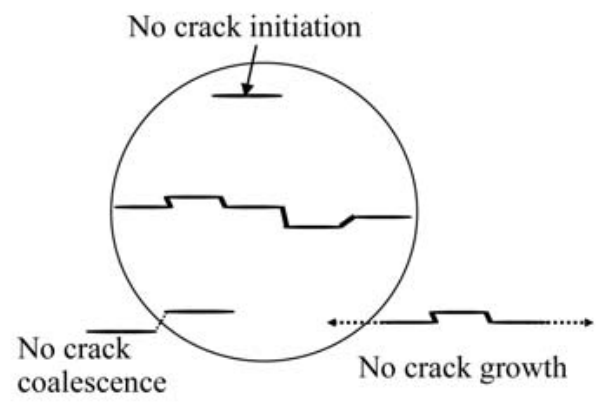

Fig. 5 Inactive region around a pre-existing crack.

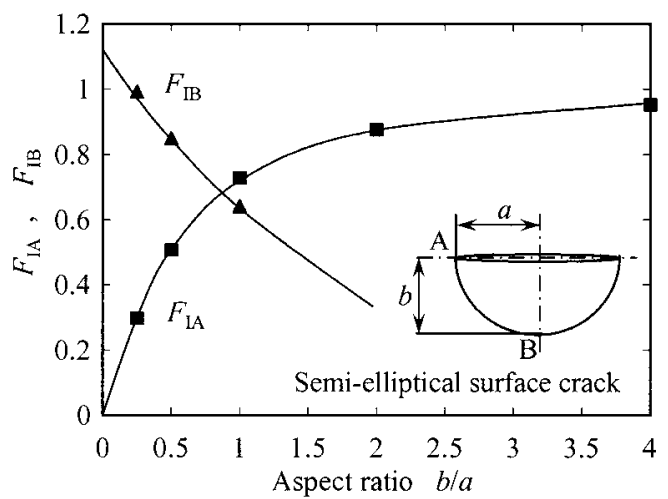

Fig. 6 Correction factors as functions of an aspect ratio for a semi-elliptical surface crack.

域の応力值を用いて計算した。すなわち, 応力拡大係数 の評価には近似的な方法を用いた。

Step 5 ：き裂合体に関しては，き裂先端の活性化領域 を考慮することにより，き裂先端の円形領域内に他のき

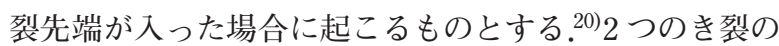
合体領域の臨界半径は次式で表される。

$$
r_{\mathrm{c}}=\frac{k}{\pi}\left(\frac{K_{\mathrm{IA}}}{\sigma_{y s}}\right)_{\mathrm{crack} 1}^{2}+\frac{k}{\pi}\left(\frac{K_{\mathrm{IA}}}{\sigma_{y s}}\right)_{\text {crack } 2}^{2}
$$

ここで， $K_{\mathrm{IA}}$ は各き裂の表面部での応力拡大係数， $\sigma_{y s}$ は 材料の降伏応力, $k$ は材料, 環境に依存する係数である. いくつかのき裂同士が合体条件を満たす場合には，条件 を満たす全てのき裂の組について先端間距離 $d$ を計算し, これを該当するき裂同士で作る合体領域半径 $r_{\mathrm{c}}$ で除した 值 $d / r_{\mathrm{c}}$ が最も小さいき裂同士を合体させる。これにより， 先端間距離が短くて大きなき裂同士であるほど合体しや すくなり，一個のき裂とのみ合体するということになる。 表面き裂の合体に関しては，合体後の表面き裂の表面寸 法は合体前の 2 個のき裂を含んだ長さ，深さ寸法は 2 個 のき裂のうち深いほうの寸法とする。したがって，表面 き裂の合体によりアスペクト比 $b / a$ の小さい表面き裂と なる。

Step 6 ：合体により進展性き裂長さあるいは $K_{\text {ISCC }}$ に 達したき裂はき裂進展特性（ $d a / d t-K_{\mathrm{I}}$ 関係）に基づいて 定常進展を開始し，き裂進展量は表面方向では表面部で の応力拡大係数 $K_{\mathrm{IA}}$, 深さ方向では最深部での応力拡大 係数 $K_{\mathrm{IB}}$ を用いて計算される。

また，き裂の合体と進展は既に存在するき裂による応 力解放の影響を受けるので, Fig. 5 に示すように，その 領域のき裂とは合体せず，その領域の中へは進展しない ものとした。ただし，深い大きな表面き裂は内部では進 展可能であり，小さな表面き裂による応力解放の影響を 制限するため，ここでは，既存き裂よりも 2 倍以上深い き裂は既存き裂による応力解放域の中に進展できるもの とした。

Step 7 ：Step 3 から Step 6 の過程を新しいき裂に対し て繰り返し，シミュレーションは，最大き裂が設定した 臨界長さに達するか, 発生可能なき裂が全て発生したと きに, 時間経過に対するき裂の分布, 各き裂の表面寸法, 深さ寸法を出力して終了する. 
4 応力分布下の SCC シミュレーション

シミュレーションは鋭敏化処理したSUS304 の高温高 純度水環境 $\left(288^{\circ} \mathrm{C}\right)$ を想定し, Fig. 3 に示されるような $y$ 軸方向の引張応力 $\sigma_{y}$ が $x$ 軸方向に分布する $20 \mathrm{~mm} \times$ $10 \mathrm{~mm}$ の長方形領域と Fig. 7 に示されるような $y$ 軸方向 に分布する $10 \mathrm{~mm} \times 20 \mathrm{~mm}$ の長方形領域に対して行っ た.これらはFig. 1 に示すような溶接線近傍の残留応力 分布を模擬したものである。平均粒径を $0.08 \mathrm{~mm}$ として， これらの領域を $20 \mathrm{~mm} \times 2 \mathrm{~mm}$ の長方形領域に 5 分割す ると, 各領域の発生可能なき裂数は 6250 個となり, 全 領域にわたる発生可能なき裂総数は 31250 個とした。降 伏応力は, SUS304 の $288^{\circ} \mathrm{C}$ での応力ーひずみ関係より $\sigma_{y s}=162 \mathrm{MPa}$ とし，作用応力はいずれの領域に対しても $y$ 軸方向に引張応力が作用するものと仮定し, 中央領域 が最も高く，外側の領域ほど低くなるように設定し，領 域 III で $200 \mathrm{MPa}$ ，領域 II IVで $160 \mathrm{MPa}$ ，領域 I, Vで $120 \mathrm{MPa}$ とした。微小き裂発生の累積確率分布は式 (1) の指数分布を仮定し，中央領域が最もき裂発生速度が大 きく, 外側の領域ほど小さくなるように設定し，領域四 で $a_{i}=0.0258 \mathrm{Ms}, \theta_{i}=2.97 \mathrm{Ms}$, 領域 II, IVで $a_{i}=0$. 0652Ms, $\theta_{i}=7.50 \mathrm{Ms}$, 領域 I, Vで $a_{i}=0.3 \mathrm{Ms}, \theta_{i}=$

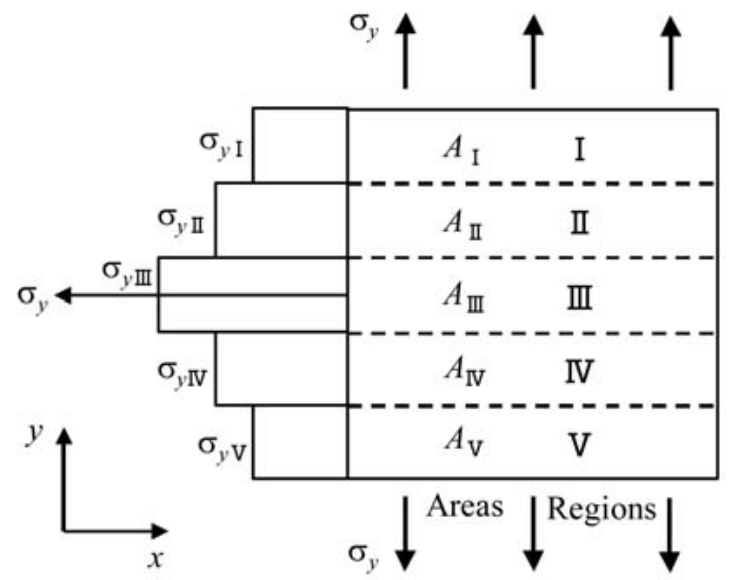

Fig. 7 Simulation area under non-uniform stress condition.
34.54Ms とした。領域四における解析条件は，前報 ${ }^{14)} に$ おけるものと同じであり，これを基準に他の領域の解析 条件を設定した。各領域に対する発生可能数 6250 個の き裂に対する発生時間をそれぞれの指数分布に基づく乱 数で割り当て, 全領域で発生時間の短いものから発生さ せた。き裂発生位置 $(x, y)$ は, 各座標に対して区間 0 〜 $2 \mathrm{~mm}$ ，区間 $0 \sim 20 \mathrm{~mm}$ の一様乱数により，き裂長さ $2 a$ は, 粒径と同程度の大きさとして, 平均長さ $0.08 \mathrm{~mm}$, 標 準偏差 $0.03 \mathrm{~mm}$ の正規乱数により決定し，アスペクト比 は $b / a=1$ とした。また，き裂の合体条件は，式 (6)にお いて $k=0.5$ とした。進展性き裂長さに対しては， $K_{\mathrm{ISCC}}=$ $2 \mathrm{MPa} \sqrt{m}$ とし, き裂表面部, 最深部の応力拡大係数が この值を超えたとき，それぞれ表面方向打よび深さ方向 に進展し始めるものとし，き裂進展速度はSUS304 に対 し提案されている $d a / d t-K_{\mathrm{I}}$ 関係 ${ }^{6}$ に従うものとした. 2Ms（555 時間）経過時点でシミュレーションを終了する ものとし，以上の条件でそれぞれ 15 回のシミュレーショ ンを行った。

\section{5 結果および考察}

\section{$5 \cdot 1 \sigma_{y}$ が $\boldsymbol{x}$ 軸方向に分布している場合}

Fig. 3 に示すように $\sigma_{y}$ が $x$ 軸方向に分布している場合 のシミュレーション結果を示し考察する．Fig. 8 はシミュ レーションによって得られたき裂分布の時間に対する変 化を示したものである. 100 時間経過時点では，微小き裂 が応力分布に応じて発生して打り, 特に高い応力となっ ている中央部ではき裂密度が高くなっている，300 時間 経過後では，さらにき裂が発生するとともに，中央部に き裂の合体と進展により大きく成長したき裂が観察され るようになる，500 時間経過後では，中央部に大きなき 裂が多数並んでいる様子が観察されるが，300 時間と比 較すると，中央領域では新たなき裂の発生はあまり見ら れず，隣接する領域へ合体や進展によりき裂が成長して いることがわかる. Fig. 9 は 15 回のシミュレーションに 対して各領域におけるき裂の発生数と時間の関係を示し たものである. 図中には各領域の指数分布に基づく計算

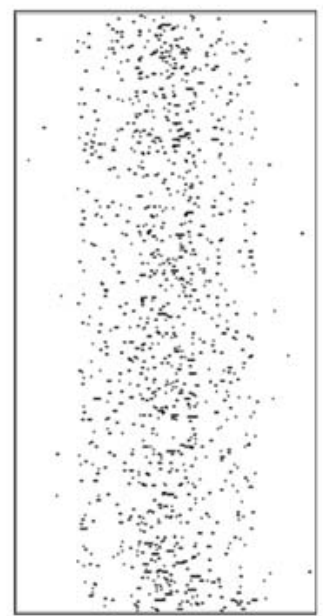

(a) $100 \mathrm{hr}$

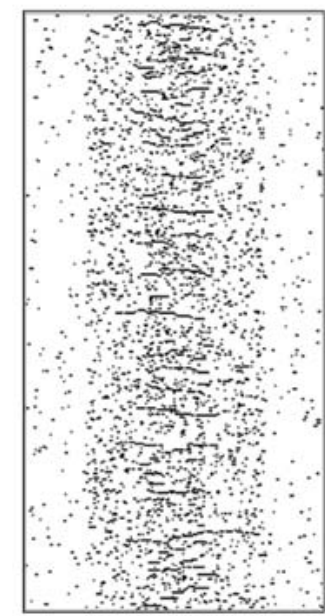

(b) $300 \mathrm{hr}$

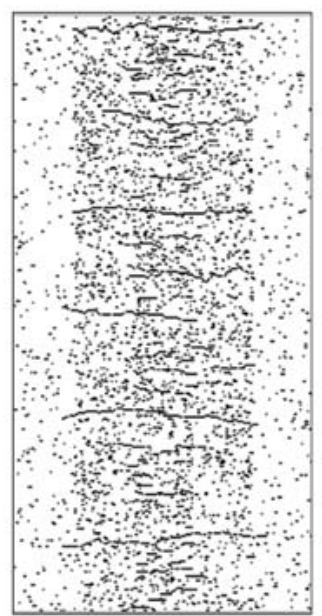

(c) $500 \mathrm{hr}$

Fig. 8 Variation of crack distribution with time under the stress distribution of Fig. 3. 


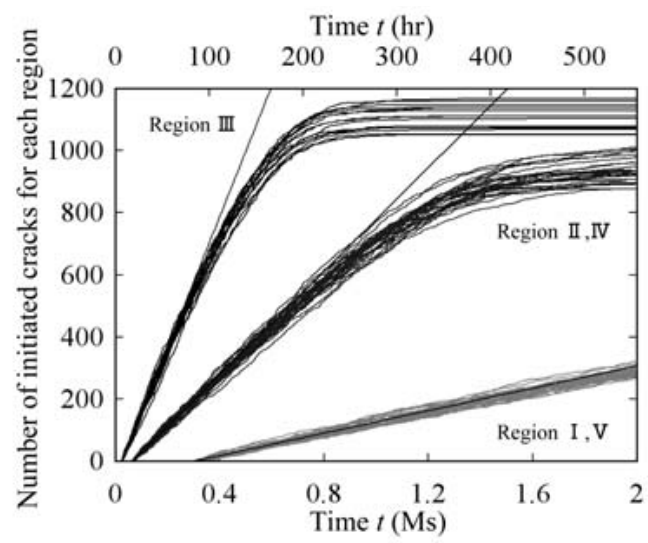

Fig. 9 Number of initiated cracks for each region as a function of time. (Stress distribution of Fig. 3)

結果も示してある．最も応力が高く，き裂発生速度の大 きい領域而のき裂発生数は初期段階では指数分布による き裂数とほぼ等しくなっているが，時間の経過とともに 合体や進展などにより大きなき裂が形成され，き裂発生 不可能領域が広がり，飽和状態となっている。一方，I， V 領域ではき裂数が少なく, 大きなき裂がほとんどない ためにき裂発生不可能領域が形成されず，発生き裂数は ほぼ指数分布に基づくものに従う結果となっている。領 域 II , IVについては $200 〜 300$ 時間経過後より指数分布 からずれ始めているが，これはき裂数の増加とともに中 央領域から成長してきた大きなき裂による影響が大きい と考えられる. Fig. 10 は最大き裂長さを時間に対して示 したものである， $2 \mathrm{~mm}$ を超えた時点から，小さなき裂と の合体と進展を繰り返すことで成長している。これは，1 つの領域の $x$ 方向の長さは $2 \mathrm{~mm}$ であり, 中央の領域 III で形成された大きなき裂が隣接領域に入り, 進展を阻害 する大きなき裂が存在しないために進展しやすい状態に あるためである。さらに，6mm を超えた時点からは，ほ ぼ進展による成長となっている。これは，き裂が発生し にくい外側の I, V領域に大き裂の先端が入り，合体する き裂や進展を阻害するき裂がさらに減少するためである. これより，低応力域では進展がき裂の成長に対し支配的 になり，応力がさらに低くなるとき裂の進展が止まる可

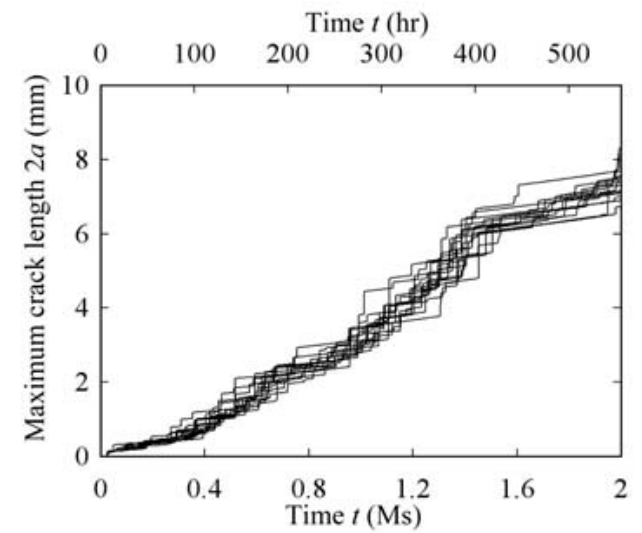

Fig. 10 Maximum crack length as a function of time. (Stress distribution of Fig. 3)
能性が考えられる. Fig. 11 は最大き裂深さを時間に対し て示したものである。深さ方向に対しては進展を阻害する ものや合体がないため進展により成長し、シミュレーショ ンによるばらつきも小さい．Fig. 12 は最大き裂長さを持 つき裂のアスペクト比と時間の関係を示したものである. 微小き裂は発生時にアスペクト比 1 の半円状表面き裂と なっているが，合体することによりアスペクト比は大き く低下する，先の後，深さ方向に進展するためアスペク 卜比は増加する。これを繰り返し，時間の経過とともに き裂が大きくなるにしたがって，アスペクト比は 0.2 0.4 に低下寸る。これは実際に見られる SCC き裂の特徴 をよく表している..

\section{$5 \cdot 2 \sigma_{y}$ が $\boldsymbol{y}$ 軸方向に分布している場合}

続いて, Fig. 7 に示すように $\sigma_{y}$ が $y$ 軸方向に分布して いる場合のシミュレーション結果を示し考察する. Fig. 13 のき裂分布の時間に対する変化に打いては，100 時間経 過時点では，微小き裂が応力分布に応じて発生しており， 特に高い応力となっている中央部ではき裂密度が高く なっている. 300 時間経過後では，さらにき裂が発生する とともに, 中央部にき裂の合体と進展により大きく成長 したき裂が観察されるようになる。 500 時間経過後では， 中央の高応力領域に沿って大きなき裂が多数存在する様 子が観察される. Fig. 14 の各領域に打けるき裂の発生

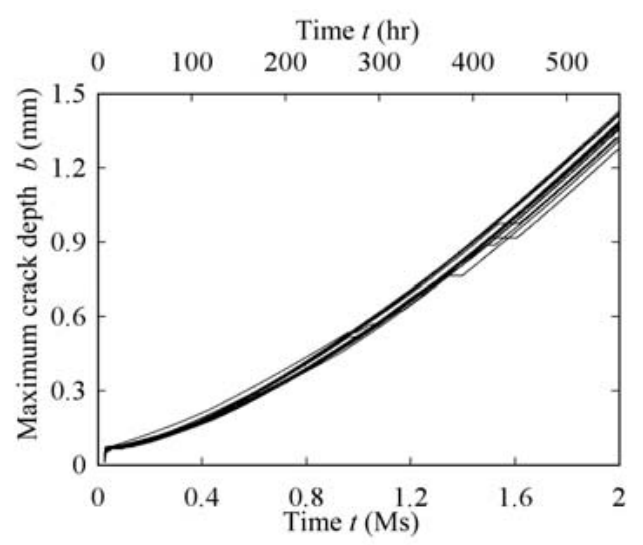

Fig. 11 Maximum crack depth as a function of time. (Stress distribution of Fig. 3)

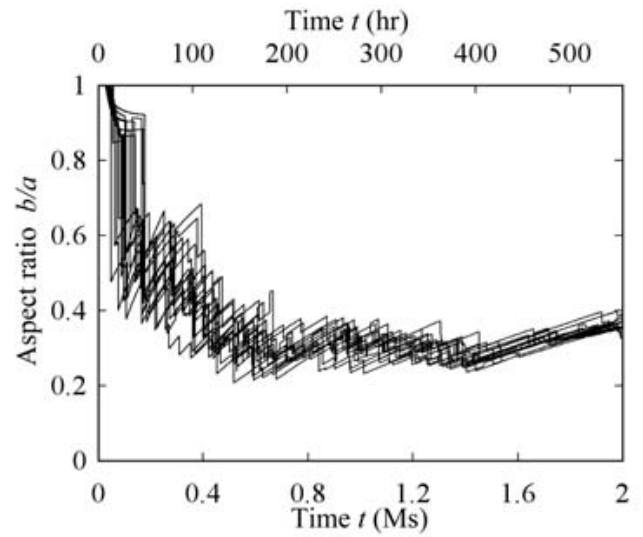

Fig. 12 Aspect ratio of the longest crack as a function of time. (Stress distribution of Fig. 3) 


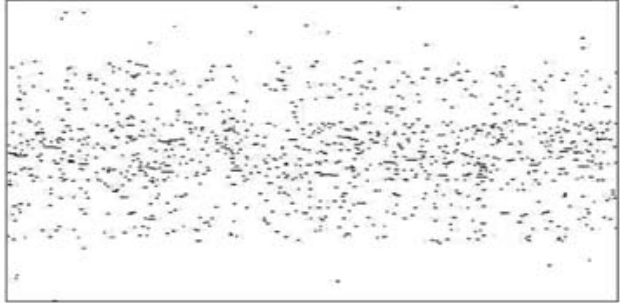

(a) $100 \mathrm{hr}$

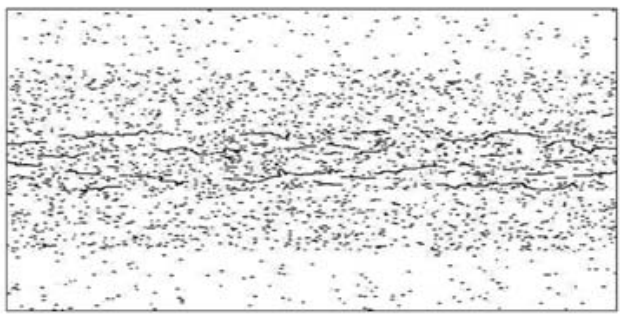

(b) $300 \mathrm{hr}$

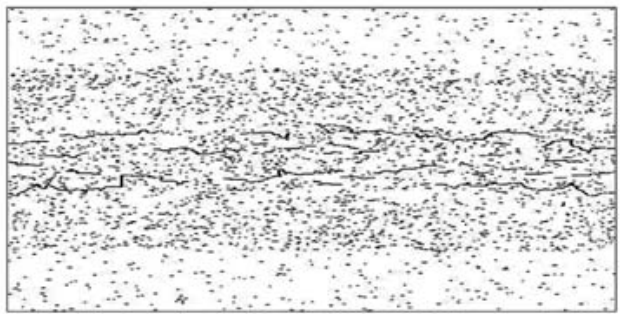

(c) $500 \mathrm{hr}$

Fig. 13 Variation of crack distribution with time under the stress distribution of Fig. 7 .

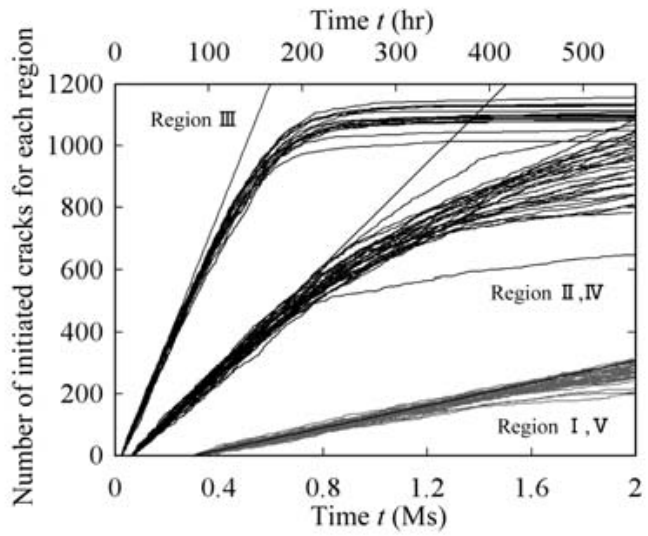

Fig. 14 Number of initiated cracks for each region as a function of time. (Stress distribution of Fig. 7)

数に関して, Fig. 9 と比較すると, 領域 III および領域 I, Vについては同じような傾向を示しているが，領域II, IV ではばらつきが大きくなっている。これは $x$ 軸方向に応 力分布を有する場合では, 高応力領域からき裂の進展に よる影響を受けていたのに対し,$y$ 軸方向に応力分布を 有する場合では，領域境界近傍における大きなき裂によ る応力解放域の影響を受けるためである。Fig. 15 に示 す最大き裂長さの時間に対する変化は, Fig. 10 とは異 なり，大きなき裂は高応力領域に沿って成長するために 合体が起こりやすく, 発生と合体が支配的となっている.

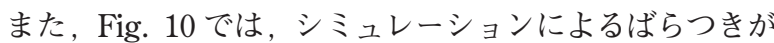
小さいのに対して，Fig. 15 では，大きなき裂が密集して

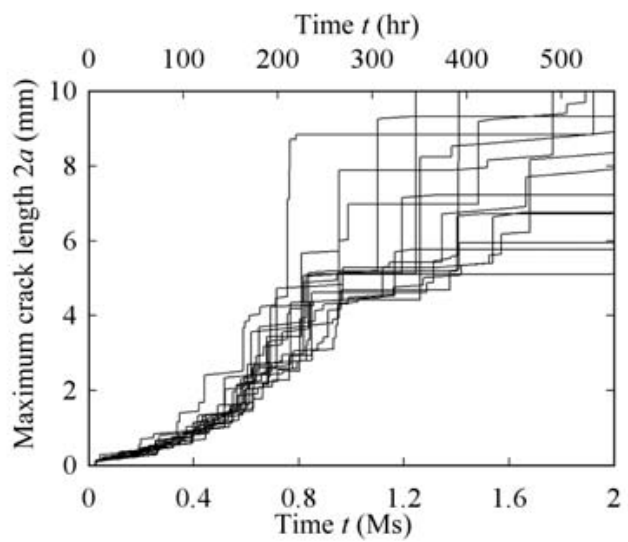

Fig. 15 Maximum crack length as a function of time. (Stress distribution of Fig. 7)

形成されることにより応力解放域が形成され，き裂の合 体および進展が生じにくくなるために最大き裂長さが停留 する場合もあり，ばらつきも大きい．Fig. 16 の最大き裂 深さに関しては, Fig. 11 と同様に深さ方向へは進展によ り成長し，ばらつきも小さい. Fig. 17 に示す最大き裂 長さを持つき裂のアスペクト比は合体により $0.2 \sim 0.4$ 程 度に低下するが，き裂の表面方向への成長が停留すると， 深さ方向には進展を続けるのでアスペクト比は大きくな る傾向にある．Fig. 12 と比較するとばらつきがやや大き くなっている.

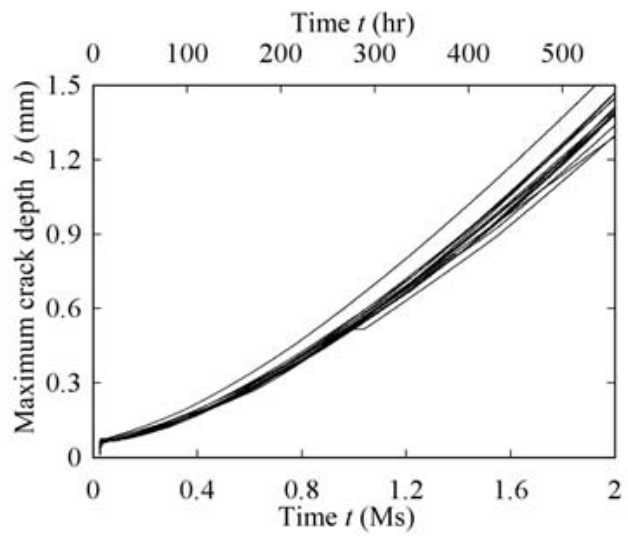

Fig. 16 Maximum crack depth as a function of time. (Stress distribution of Fig. 7)

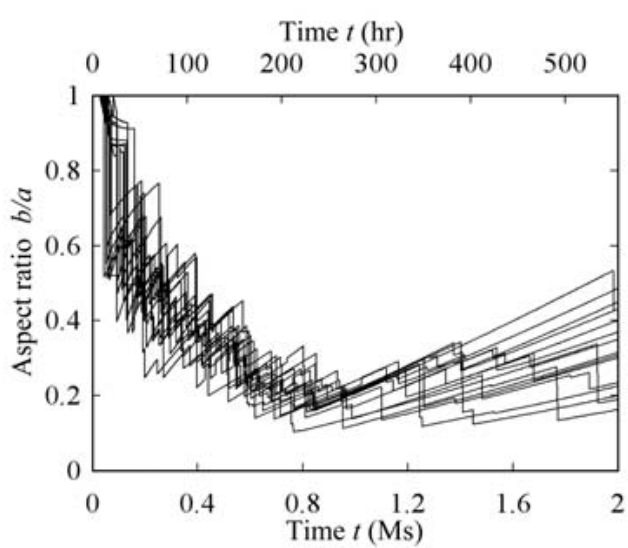

Fig. 17 Aspect ratio of the longest crack as a function of time. (Stress distribution of Fig. 7) 
以上の $\sigma_{y}$ が $y$ 軸方向に分布している場合は, き裂進展 方向 $(x$ 軸方向 $)$ への応力分布は一様であるため, シミュ レーション結果の最大き裂長さ (Fig. 15) , 最大き裂深さ (Fig. 16) , 最大き裂のアスペクト比 (Fig. 17) に及ぼす $y$ 軸方向応力分布の影響は小さく, 前報の一様応力場のシ ミュレーション結果とほぼ同様な結果となっている.

\section{6 結}

\section{言}

本研究では, 応力分布下の SCC 挙動を予測するため に, 前報で開発した一様応力場での SCC 挙動のモンテ カルロ・シミュレーションをさらに応力分布が考慮でき るように拡張した. SUS 304 における溶接部近傍の残留 応力を模擬した 2 種類の応力分布下で SCC 挙動のシミュ レーションを行った結果, 溶接線に垂直に形成された多 数のき裂や HAZ に沿って形成された多数のき裂の状況 を示すことができた。このようなき裂の事例として，原 子炉内のシュラウドサポート溶接部, 15)シュラウドリング 溶接部 ${ }^{16)}$ その他 $\left.{ }^{17)}, 18\right)$ に報告されている。実際には，溶 接金属, 母材, HAZ など材料の SCC 感受性の違いの影 響もあり直接の比較はできないが, 本シミュレーション において事例に類似したき裂の様子が得られたことは， 本シミュレーションの可能性を示唆するものである.

本シミュレーションは, き裂発生条件, き裂合体条件, き裂進展特性，さらに材料の SCC 感受性に関する不均 質性など適切なインプットデータを用いるならば, 応力 分布を考慮した実機における SCC 挙動, 寿命予測に有 効な手法になり得るものと考えられる.

\section{参 考 文 献}

1) M. Akashi and G. Nakayama, "Stress-Corrosion Crack Initiation Process Model for BWR Plant Materials”, Proceedings International Symposium on Plant Aging and Life Prediction of Corrodible Structures, T. Shoji and T. Shibata, Eds., JSCE-NACE International, pp.99-106 (1997).

2 ) K. Nakanishi, Y. Tanaka, K. Yoshida and M. Akashi, "Effects of Applied Stress on the Stress-Corrosion Cracking Lifetime of Carbon Steel Weld Metal in High-Purity Water Environment at 250C", Proceedings International Symposium on Plant Aging and Life Prediction of Corrodible Structures, T. Shoji and T. Shibata, Eds., JSCE-NACE International, pp.691-698 (1997).

3) M. Akashi and G. Nakayama, "A Process Model for the Initiation of Stress-Corrosion Crack Growth in BWR Plant Materials”, ASTM STP 1281, pp.150-164 (1997).

4 ) M. Kamaya, G. Chiba, N. Nakajima and N. Totsuka, "Multiple Cracks Initiation and Propagation Behavior of Stainless Steel in High Temperature Water Environment”, Zairyo-toKankyo, Vol.50, pp.57-64 (2001).

5 ) M. Kamaya and T. Haruna, "Influence of Local Stress on Initiation of Stress Corrosion Cracking for 304 Stainless Steel”, Proceedings of Zairyo-to-Kankyo 2007, pp.149-150 (2007).

$6)$ K. Saito and J. Kuniya, "Mechanical Model to Predict
Stress Corrosion Crack Growth of Stainless Steel in High Temperature Water", Corrosion Science, Vol.43, pp.1751-1766 (2001).

7 ) JSME Fitness-For-Service Code, JSME SNA1-2004 (2004).

$8)$ H. Kitagawa and Y. Nakasone, "A Monte Carlo Analysis Model of Corrosion Fatigue Process Characterized by Initiation, Growth and Coalescence of Distributed Small Cracks”, Journal of the Society of Materials Science, Japan, Vol.33, No.364, pp.14-20 (1984).

9) N. Tada, T. Kitamura and R. Ohtani, "Monte Carlo Simulation of Creep-Fatigue Small Cracks Based on a Three-Dimensional Model of Random Fracture Resistance of Grain Boundaries”, Transactions of the Japan Society of Mechanical Engineers, Ser. A, Vol.56, No.524, pp.28-34 (1990).

10) K. Fujiyama, "Computer Simulation on Fracture of Engineering Materials at High Temperature, III : Total and/or Remaining Life Assessment of Structural Material”, Journal of the Society of Materials Science, Japan, Vol.45, No.1, pp.137-142 (1996).

11) Y.-Z. Wang, D. Hardie and R. N. Parkins, "The Behaviour of Multiple Stress Corrosion Cracks in a Mn-Cr and Ni-CrMo-V Steel : III Monte Carlo Simulation”, Corrosion Science, Vol.37, No.11, pp.1705-1720 (1995).

12) M. Kamaya and T. Kitamura, "A Simulation on Growth of Multiple Small Cracks under Stress Corrosion”, International Journal of Fracture, Vol.130, pp.787-801 (2004).

13) K. Tohgo and N. Ogai, "Monte Carlo Simulation of Stress Corrosion Cracking in Structural Metal Materials”, Key Engineering Materials, Vols.306-308, pp.447-452 (2006).

14) K. Tohgo, H. Suzuki, Y. Shimamura, G. Nakayama and T. Hirano, "Monte Carlo Simulation Taking Account of Surface Crack Effect for Stress Corrosion Cracking in a Stainless Steel SUS 304", Transactions of the Japan Society of Mechanical Engineers. Ser. A, Vol.74, No.737, pp.128-136 (2008).

15) Homepage of The Japan Atomic Power Company, http://www.japc.co.jp/news/bn/h11/111210.html.

16) Homepage of Ministry of Economy, Trade and Industry, http://www.meti.go.jp/report/data/g41022bj. html.

17) M. Rivera, S. Bolinger and C. Wollenweber, "Carbonate Cracking Risk Assessment for a FCCU Gas Plant”, Corrosion 2004, Paper No.04639, NACE International (2004).

18) E. Yamamoto, "Damage to Stainless Steel at Chemical Plants and Countermeasures", Symposium on Recent Progress in Welding Technology from the Viewpoint of Stainless Steels, The Iron and Steel Institute of Japan, pp.1-10 (2002).

19) Y. Murakami and H. Nishitani, "Stress Intensity Factor for Interacting Two Equal Semi-Elliptical Surface Cracks in Tension”, Transactions of the Japan Society of Mechanical Engineers, Ser. A, Vol.47, No.415, pp.295-303 (1981).

20) H. Kitagawa, T. Fujita and K. Miyazawa, "Small Randomly Distributed Cracks in Corrosion Fatigue”, ASTM STP 642, pp.98-114 (1978). 